\title{
DOGOTERAPIA JAKO METODA WSPOMAGANIA PROCESU REHABILITACJI DZIECI
}

\section{DOG THERAPY AS A METHOD OF SUPPORTING CHILDREN'S REHABILITATION PROCESS}

\author{
Sławomir Chrost ${ }^{1(\mathrm{~A}, \mathrm{~B}, \mathrm{C}, \mathrm{D}, \mathrm{E}, \mathrm{F}, \mathrm{G})}$
}

${ }^{1}$ Uniwersytet Jana Kochanowskiego w Kielcach

Chrost, S. (2018). Dogoterapia jako metoda wspomagania procesu rehabilitacji dzieci. Rozprawy Społeczne, 12(3), 64-72. https://doi.org/10.29316/rs.2018.22

Wkład autorów:

A. Zaplanowanie badań

B. Zebranie danych

C. Dane - analiza i statystyki

D. Interpretacja danych

E. Przygotowanie artykułu

F. Wyszukiwanie i analiza

literatury

G. Zebranie funduszy
Tabele: 0

Ryciny: 0

Literatura: 18

Otrzymano: grudzień 2017

Zaakceptowano: kwiecień 2018

\section{Streszczenie}

Wstęp. Autor artykułu przedstawia, na podstawie badań, korzyści z zastosowania dogoterapii we wspomaganiu rozwoju i rehabilitacji dzieci.

Materiał i metody. W badaniach przeprowadzonych na terenie województwa świętokrzyskiego zastosowano metodę indywidualnych przypadków, posłużono się techniką wywiadu, którego udzieliło siedem osób (dwie terapeutki i pięcioro rodziców), które opisały przypadki siedmiorga dzieci uczestniczących w procesie dogoterapii. Dzieci (Kamila, Karolina, Karol, Bartek, Mateusz, Sylwia, Miłosz) były w przedziale wiekowym 6-11 lat i każde z nich przejawiało trudności w prawidłowym rozwoju lub było dotknięte niepełnosprawnością.

Wyniki. Badania ukazały, że głównymi korzyściami z zastosowania dogoterapii jest zdecydowana poprawa w różnych sferach: sferze społecznej (kontaktów interpersonalnych), sferze samooceny (rozwinięta śmiałość i odwaga), sferze senso-motorycznej (mówieniu, czytaniu, poruszaniu się, kontrolowaniu emocji), sferze motywacji do działania czy rozwinięcia poczucia odpowiedzialności. Wnioski. Z zebranego materiału badawczego wynika, że obecność czworonoga na zajęciach pozwala dziecku odprężyć się, wyciszyć, obniża poziom lęku oraz kształtuje trwałą więź. Należy pamiętać, że do zajęć dogoterapeutycznych nie mogą być skierowani pacjenci posiadający otwarte rany na ciele, alergię na sierść psa, przejawiający paniczny lęk wobec zwierząt, pacjenci agresywni, z ADHD, pacjenci ze schorzeniami psychicznymi. Z tych powodów wybór dogoterapii jako metody wspomagającej rehabilitację powinien być wcześniej potwierdzony odpowiednimi informacjami na temat stanu zdrowia psychicznego pacjenta, poziomu jego agresji oraz występowania innych cech niepożądanych.

Słowa kluczowe: dogoterapia, animaloterapia, wspomaganie rozwoju i rehabilitacji

\section{Summary}

Introduction. The author of the article presents, on the basis of research, the benefits of using dog therapy in supporting the development and rehabilitation of children.

Material and methods. In the research conducted in Świętokrzyskie Province, the method of individual cases was applied, the interview technique was employed with interviews given by seven people (two therapists and seven parents), who described cases of seven children participating in dog therapy. Children (Kamila, Karolina, Karol, Bartek, Mateusz, Sylwia, and Miłosz) were in the age group of 6-11 years. Each of them manifested difficulties in normal development or were affected by disability.

Results. The research showed that the main benefit of applying dog therapy is a definite improvement in various spheres: the social sphere (interpersonal contacts), self-esteem (development of boldness and courage), the sensorimotor sphere (speaking, reading, walking, controlling emotions), motivation to take action or to develop a sense of responsibility.

Conclusions. The collected research material demonstrates that the presence of a dog in the classroom allows the child to relax and calm down. It also lowers the level of anxiety and shapes a lasting bond. It should be noted that patients with open wounds on the body, allergic to dog's fur, having obsessive fear of animals, aggressive ones, patients having mental disorders or ADHD, cannot be referred for dog therapy activities. For these reasons, choosing dog therapy as a method of rehabilitation should be previously confirmed by appropriate information on the patient's mental health, the level of their aggression and other undesirable traits.

Keywords: dog therapy, animal therapy, development and rehabilitation support

Adres korespondencyjny: Sławomir Chrost, Uniwersytet Jana Kochanowskiego w Kielcach, Wydział Pedagogiczny i Artystyczny, ul Krakowska 11, 25-029 Kielce, e-mail: schrost@ujk.edu.pl; ORCID: https://orcid.org/0000-0001-6787-5379 Copyright by: Państwowa Szkoła Wyższa im. Papieża Jana Pawła II w Białej Podlaskiej, Sławomir Chrost

Czasopismo Open Access, wszystkie artykuły udostępniane są na mocy licencji Creative Commons Uznanie autorstwa-użycie niekomercyjne-na tych samych warunkach 4.0 Międzynarodowe (CC BY-NC-SA 4.0, http://creativecommons.org/licenses/by-nc-sa/4.0/). 


\section{Wstęp}

W 1792 roku w Wielkiej Brytanii udokumentowano pierwszy zaplanowany i celowy przypadek udziału zwierząt w procesie terapeutycznym. Zaproponowano hospitalizowanym pacjentom szpitala psychiatrycznego York opiekę nad małymi zwierzętami, co miało wpłynąć pozytywnie na proces kształtowania samokontroli. W Niemczech w 1867 roku w szpitalu Bielefield pacjenci chorzy na epilepsję $\mathrm{w}$ specjalnie wybudowanym parku mieli nieograniczony kontakt ze zwierzętami, natomiast po pierwszej wojnie światowej w szpitalu sił powietrznych Stanów Zjednoczonych w Pawling zachęcano chorych do kontaktu $\mathrm{z}$ małymi gospodarskimi zwierzętami. Najistotniejszym wydarzeniem w historii dogoterapii są publikacje Borisa Levinsona - amerykańskiego psychologa dziecięcego, nazywanego w literaturze polskiej "Ojcem dogoterapii". Pierwsza z nich nosiła tytuł "Pet-Oriented Child Psychotherapy" z 1969 roku, a druga „Pets and Human Development” z 1972 roku. Levison swoje obserwacje rozpoczął w 1953 roku po przyjeździe młodego pacjenta, który spotkał się z psem swojego terapeuty - Jinglesem. Pies znacznie pomógł w nawiązaniu kontaktu z dzieckiem oraz $\mathrm{w}$ zbudowaniu zaufania dzięki czemu cała terapia przebiegła szybciej i z pomyślnym skutkiem. Pierwsze obserwacje ujął w 1964 roku $\mathrm{w}$ artykule zatytułowanym „The dog as a co - therapist" (Otto, 2010, s. 183).

W Polsce termin dogoterapia został użyty po raz pierwszy w roku 1996 przez Marię Czerwińską podczas trwania konferencji prasowej organizowanej z okazji Światowego Dnia Zwierząt na określenie doświadczenia z kontaktów psów z dziećmi, które odbyły się najpierw na planie filmu zatytułowanego „Widzę", a później wielu oddziałach w polskich szpitalach. Maria Czerwińska założyła w 1998 roku fundację „CZE-NE-KA” co w języku Indian północnoamerykańskich oznacza wiecznie śmiejacy się pies, wesoły pies. W 2002 roku założono fundacje Przyjaciel w Warszawie i Dogtor w Trójmieście, w 2003 fundacje Ama Canem i Cane Pro Humano, a w 2004 fundację Właśnie Tak! w Bydgoszczy. W 2006 roku w Warszawie powstaja organizacje takie jak Pies dla Stasia i Razem Łatwiej oraz Mały Piesek Zuzi w Poznaniu.

Momentem przełomowym w ustabilizowaniu sytuacji dogoterapii w Polsce było powołanie w 2006 roku Polskiego Towarzystwa Kynoterapeutycznego, które wprowadziło termin kynoterapia. Celem PTK jako było objęcie opieką merytoryczną organizacji oraz osób działających w obrębie dogoterapii, a także stworzenie odpowiednich standardów pracy. Działalność Polskiego Towarzystwa Kynoterapeutycznego doprowadziła do wpisania1 lipca 2010 roku zawodu kynoterapeuta (dogoterapeuta) do Klasyfikacji Zawodów i Specjalności na Potrzeby Rynku Pracy, prowadzonej przez Ministerstwo Pracy i Polityki Społecznej.
Dogoterapia w Polsce traktowana jest jako stosunkowo nowa metoda wspomagająca proces rozwoju i rehabilitacji dzieci oraz młodzieży. Dogoterapia zwana inaczej kynoterapią jest jedną z wielu form powszechnie znanej już animaloterapii, która wykorzystuje udział zwierząt $\mathrm{w}$ procesie leczenia. W ostatnich latach zyskała dużą popularność jako pożądana metoda wspomagająca, wykorzystująca odpowiednio dobranego czworonoga do pracy z dziećmi z niepełnosprawnościami oraz mającymi problemy w zakresie rozwojowym. Wspomagający charakter dogoterapii wynika przede wszystkim ze współpracy zarówno dogoterapeuty, psa uczestniczącego, dziecka, rodziców, pedagogów oraz innych podmiotów zaangażowanych w przedsięwzięcie.

Zamierzeniem autora artykułu jest znalezienie odpowiedzi na pytanie: Jakie są korzyści z zastosowania dogoterapii we wspomaganiu rozwoju i rehabilitacji? W badaniach, które stanowią fundament do analiz, przeprowadzonych na terenie województwa Świętokrzyskiego zastosowano metodę indywidualnych przypadków, posłużono się techniką wywiadu, którego udzieliło siedem osób (dwie terapeutki i pięcioro rodziców). Opisano przypadki siedmiorga dzieci uczestniczących $\mathrm{w}$ procesie dogoterapii. Dzieci (Kamila, Karolina, Karol, Bartek, Mateusz, Sylwia, Miłosz) były w przedziale wiekowym 6-11 lat i każde $\mathrm{z}$ nich przejawiało trudności w prawidłowym rozwoju lub było dotknięte niepełnosprawnością.

\section{Dogoterapia - definicja, cele, metody pracy}

Terapia prowadzona $\mathrm{z}$ udziałem zwierząt stała się w ostatnich latach metodą popularną i coraz bardziej dostępną. Powstało mnóstwo fundacji oraz stowarzyszeń, a także działalności jednoosobowych wykorzystujących i oferujących tę metodę jako formę pomocniczą w procesie rozwoju i rehabilitacji dzieci, młodzieży, dorosłych i osób starszych. Wiele ośrodków w Polsce posiada w swojej ofercie dogoterapię co świadczy o szybkim rozwoju zjawiska (Pawlik-Popielarska, 2005, s. 3).

Dogoterapia wchodzi w skład szeroko rozumianej animaloterapii, która jest tłumaczona jako: „naturalna metoda wspomagania leczenia i rehabilitacji osób niepełnosprawnych oparta na bezpośrednim kontakcie ze zwierzętami. Adresatami są w szczególności dzieci z problemami emocjonalnymi oraz z zaburzeniami i deficytami rozwoju psychoruchowego" (Franczyk, Krajewska, Skorupa, 2012, s. 9).

Według Gabrieli Drwięgo oraz Zofii Pietruczu dogoterapia jest jedną $\mathrm{z}$ form animaloterapii inaczej zwanej zooterapią, w skład której wchodzą: felinoterapia czyli terapia z udziałem kotów, hipoterapia czyli terapia z udziałem koni, delfinoterapia, czy tak zwana pet therapy czyli terapia z udziałem zwierząt takich jak: alpaki, chomiki, króliki, świnki morskie, gady, ptaki i płazy.

W Polsce w odniesieniu do terapii z udziałem psa funkcjonuje poza terminem dogoterapia kilka 
terminów zamiennych takich jak kynoterapia czy canisterapia, jednakże określenie dogoterapia jest najdłużej funkcjonującym i powszechnie zrozumiałym. Jest to metoda, która wykorzystuje psy w celu wieloprofilowego usprawniania dzieci oraz osób dorosłych, uważana jest za naturalną formę rehabilitacji niepełnosprawnych (Drwięga, Pietruczuk, 2015).

Jedna z trafniejszych definicji dogoterapii została opracowana przez Fundację na Rzecz Wspomagania Rehabilitacji i Szerzenia Wiedzy Kynologicznej Mały Piesek Zuzi z Poznania, według której: „dogoterapia to metoda wspomagania rehabilitacji i terapii osób niepełnosprawnych fizycznie, intelektualnie, emocjonalnie i społecznie, w której wykorzystywane są specjalnie wyselekcjonowane i wyszkolone psy. Nad całością czuwa zespół terapeutyczny" (Nawrocka, 2009, s. 125).

Beata Kulisiewicz definiuje dogoterapię następująco: „to terapia wykorzystująca kontakt z psem. W czasie zajęć i zabaw naturalna spontaniczność i radość psa pozwalają dziecku odczuć satysfakcję z wykonywanych przez nie zadań, a nade wszystko mobilizują go do podejmowania nowych wyzwań" (Kulisiewicz, 2007, s. 7).

Anna Franczyk, Katarzyna Krajewska i Joanna skorupa uważają, że jedno z głównych działań terapii kontaktowej jaką jest dogoterapia polega na nawiązaniu psychicznej więzi pacjenta ze zwierzęciem, co pomaga przyspieszyć leczenie, a ponadto ma korzystny wpływ na rozwój psychospołeczny (Franczyk, Krajewska, Skorupa, 2012).

Inne definicje głoszą, że dogoterapia jest metodą wykorzystującą oddziaływanie specjalnie wyszkolonego i przygotowanego psa terapeuty ${ }^{1}$ na rehabilitację osób ze specyficznymi dysfunkcjami fizycznymi, psychicznymi oraz intelektualnymi. Oddziaływanie to polega na różnych formach kontaktu fizycznego, a także emocjonalnego z psem, co może skutkować poprawą jakość życia człowieka na każdym etapie rozwoju (https://dogoterapia. wordpress.com/artykuly/dogoterapia).

Cele dogoterapii można podzielić na 4 podstawowe kategorie: cele edukacyjno-poznawcze, motywacyjne, fizyczno-ruchowe i zdrowia psychicznego. Do celów edukacyjno-poznawczych zalicza się przede wszystkim wzbogacenie słownictwa a także poprawę formy wypowiedzi, poznawanie różnych pojęć takich jak wielkość, kształt czy kolor, rozwijanie dostrzegania różnic i podobieństw między nimi, rozwijanie pamięci trwałej i krótkiej, poprawa koncentracji, zwiększenie świadomości orientacji przestrzennej. Do celów motywacyjnych zalicza się: rozwijanie współpracy z uczestnikami zajęć, pobudzenie motywacji do ćwiczeń, rozwijanie motywacji do udziału w zajęciach terapeutycznych. Celami fizyczno-ruchowymi są: rozwijanie umiejętności poruszania się np. na wózku inwalidzkim, rozwijanie

Termin „pies terapeuta” stosowany w artykule wprowadzony jest w celu odróżnienia specjalnie szkolonego psa od innych psów i nie może być traktowany na równi z terminem „dogoteapeuta” (człowiek terapeuta). równowagi i funkcji motorycznych. Cele w zakresie zdrowia psychicznego to: rozwijanie umiejętności skupiania uwagi, podnoszenie poczucia wartości i pewności siebie, łagodzenie fobii i lęków, zmniejszanie uczucia izolacji i uczucia samotności, nauka relaksacji w towarzystwie psa terapeutycznego, rozwijanie porozumiewania się członków grupy oraz rozwijanie umiejętności okazywania emocji wraz z równoczesnym ich kontrolowaniem (http:// poradniakielce.pl/oferta/terapia/dogoterapia).

Beata Pawlik-Popielarska jest zdania, że prawidłowo przygotowany i zastosowany program terapeutyczny $\mathrm{z}$ udziałem psa może skutkować osiągnięciem takich celów jak: obniżenie napięcia mięśniowego, stymulowanie sprawności motorycznej, zwiększenie możliwości lokomocyjnych, poprawa w zakresie funkcjonowania emocjonalno-uczuciowego, rozwijanie umiejętności społecznych, kształtowanie charakteru i odpowiedzialności, integracja środowiska rodzinnego, stwarzanie okazji do wspólnej zabawy oraz nawiązanie naturalnej więzi ze światem zewnętrznym (Pawlik-Popielarska, 2005).

Według Marzeny Machoś-Nikodem najistotniejszą rolę $\mathrm{w}$ terapii z psem odgrywa kontakt fizyczny. „Dotyk wiąże się ze skórą, która stanowi ważny system sensoryczny organizmu dziecka. Przepływ informacji zwrotnych między skórą, mózgiem i innymi układami jest ciągły - informacja sensoryczna pochodząca z zewnątrz dociera do mózgu, gdzie następuje jej przetwarzanie, segregowanie, interpretowanie, następnie mózg wysyła informację zwrotną do skóry i innych układów, co umożliwia nam reakcję na otrzymany bodziec. Dotyk pobudza reakcje odruchowe, które wpływają na rozwój innych zmysłów. U noworodka dotyk stymuluje wzrost czuciowych końcówek nerwowych w ciele, zaangażowanych w ruchu, orientacji przestrzennej i percepcji wzrokowej. W przypadku braku uaktywniania końcówek nerwowych może dojść do zaburzeń w funkcjonowaniu aktywującego się układu siatkowego, co prowadzi do upośledzenia pracy mięśni, różnych zaburzeń emocjonalnych oraz do trudności w procesie uczenia się. Dotyk stanowi instynktowną potrzebę i podstawową formę komunikacji między ludźmi. Liczne badania dowodzą jego właściwości terapeutycznych" (Machoś-Nikodem, 2006, s. 80).

Dogoterapia może przybierać różne formy od zajęć indywidualnych po grupowe. Najczęściej wyróżnia się trzy podstawowe rodzaje pracy z psem terapeutą.

Pierwszy z nich to Animal Assisted Therapy, czyli Terapia z Udziałem Zwierząt (AAT). W metodzie tej pies, spełniający określone wytyczne jest integralną częścią całego procesu leczniczego, który jest prowadzony przez profesjonalnego terapeutę zazwyczaj lekarza lub fizjoterapeutę. Jest to proces planowany i celowy, zakłada poprawę w społecznym, fizycznym, poznawczym i emocjonalnym funkcjonowaniu pacjentów. Metoda może 
być przeprowadzana w różnym otoczeniu, zarówno w formie grupowej jak i indywidualnej. Cały przebieg procesu jest dokumentowany, są określone cele i poszczególne zadania dla uczestników, mierzony jest także postęp w rehabilitacji.

Drugą metodą jest Animal Assisted Activities czyli Zajęcia z Udziałem Zwierząt (AAA). Właściciel i jego pies odwiedzają osoby niepełnosprawne i chore w ośrodkach leczniczych, opiekuńczych oraz w domach prywatnych. Wizyta nie jest szczegółowo zaplanowana, a takie same zajęcia mogą być wykorzystywane $\mathrm{z}$ wieloma przypadkami. Celem takiej wizyty jest zwykły kontakt umożliwiający spotkanie ze zwierzęciem i zabawę. Przebieg wizyty jest zazwyczaj spontaniczny, czas trwania uzależniony jest od potrzeb. W AAA nie ma obowiązku prowadzenia dokładnych notatek, a osobą prowadzącą zajęcia mogą być wolontariusze (Filozof, 2004).

Trzecią metodą, która kładzie nacisk bardziej na edukację niż rehabilitację jest Animal Assisted Education czyli Edukacja z Udziałem Zwierząt (AAE). W jej skład wchodzą wszelkie programy edukacji humanitarnej. Zajęcia prowadzone są przez pedagoga $\mathrm{w}$ grupie dzieci $\mathrm{w}$ wieku przedszkolnym i wczesnoszkolnym. AAE dotyczy głównie przeciwdziałania przemocy wobec zwierząt, kształtowania odpowiednich zachowań wobec psów agresywnych lub obcych oraz prawidłowej i odpowiedzialnej opieki nad zwierzętami. Edukacja z Udziałem Zwierząt to także nauka pojęć, informacji oraz logicznego myślenia. Może przybierać formę lekcji matematyki z udziałem psów podczas której dzieci uczą się nieskomplikowanych działań takich jak liczenie, dodawanie czy odejmowanie przy pomocy psów (liczba psów, liczba łap i oczu i tym podobne) (http:// www.deon.pl/inteligentne-zycie/psychologia-naco-dzien/art,125,pies-na-etacie-czyli-dogoterapia).

Przebieg zajęć dogoterapeutycznych zależy w dużej mierze od wybranej metody współpracy. Jednakże zazwyczaj obowiązuje jeden schemat rozpoczynający wspólną współpracę. Na początku zbierane są informacje o pozytywnych aspektach dziecka, co lubi, co potrafi robić, jakie czynności sprawiają mu radość. Wskazane jest, aby pierwsze zajęcia odbywały się bez udziału psa, a diagnozowanie umiejętności odbywało się poprzez zabawę. Pierwsze zajęcia powinny być wykorzystane na poznanie dziecka, obserwowanie go w zabawie oraz uzyskanie zgody na bliski kontakt i akceptacji dziecka. Wiadomości zebrane podczas zajęć należy umieścić w kwestionariuszu obserwacji, a następnie określić na jego podstawie cel i opracować program pracy terapeutycznej dostosowany do indywidualnych potrzeb i możliwości dziecka. Kolejnym krokiem jest określenie barier w pracy z psem oraz tego co w tej pracy pomoże. Etapem końcowym jest ustalenie terminu realizacji programu (Kulisiewicz, 2007).

Pies uczestniczący w terapii towarzyszy dziecku w zabawach i w czasie, gdy wykonywane są ćwiczenia okazuje zainteresowanie. Dziecko dużo chętniej ułoży zadanie dla psa, opowie mu o swoich spostrzeżeniach i wątpliwościach, chętniej nauczy się czytać, gdy pies będzie go słuchał oraz łatwiej przyswoi wiedzę. Pies jest powiernikiem dziecięcych tajemnic, wsłuchuje się w głos dziecka, wyraża pełną akceptację dając tym samym poczucie bezpieczeństwa. Pies potrafi skoncentrować uwagę, zachęcić do wspólnej zabawy, pomóc przełamać lęk przed kontaktem ze światem zewnętrznym. Schemat zajęć z dogoterapii kształtuje się następująco: Zajęcia wstępne - należą do pierwszego etapu pracy i obejmują przywitanie i ćwiczenia wprowadzające, które mają pobudzić do pracy; Zajęcia właściwe - podczas których odbywa się realizacja opracowanego programu; Zajęcia końcowe - czyli podsumowanie pracy, przypomnienie nowych wiadomości i umiejętności, zajęcia uspokajające, ustalenie terminu następnego spotkania oraz pożegnanie. Po zakończonym programie dziecko otrzymuje dyplom, certyfikat lub zaświadczenie, potwierdzone na przykład odciskiem psiej łapy. Ostatnim etapem pracy jest ewaluacja, czyli oceny przebiegu procesu uczenia, postępów dziecka a także skuteczności zastosowanej metody wraz z określeniem atrakcyjności programu dla dzieci (Kulisiewicz, 2007).

„Podczas kontaktu ze zwierzęciem dzieci często reagują radością, uśmiechem, nadzwyczajnym podnieceniem. Labilność emocjonalna, która bardzo często towarzyszy niepełnosprawnym i ich rodzinom nie wpływa dobrze na rozwój emocjonalny dziecka. Dlatego, jeśli zajęcia z psem wywołują pozytywne emocje, należy pozwolić mu doświadczać jak najwięcej spotkań ze zwierzęciem" (Bartkiewicz, Zawadka, 2008, s. 63).

W książce zatytułowanej Baw się poprzez animaloterapię autorstwa Anny Franczyk, Katarzyny Krajewskiej i Joanny Skorupy szeroko rozumiana animaloterapia w skład której wchodzi dogoterapia przeznaczona jest dla dzieci zdrowych oraz dzieci z różnymi deficytami rozwojowymi, np. $\mathrm{z}$ porażeniem mózgowym, z zaburzeniami rozwoju motorycznego, z niedowładem kończyn, z zanikiem mięśni, z zespołem wiotkiego dziecka, z zespołem Downa oraz dla dzieci ze spektrum autyzmu, niestabilnych emocjonalnie, upośledzonych, czy posiadających deficyty uwagi (ADHD ADD) (Franczyk, Krajewska, Skorupa, 2012).

Osoby funkcjonujące z różnorodnymi dysfunkcjami często mają osłabioną relację z otaczającym ich światem. Niepełnosprawność sprawia, że świat ludzi z nią funkcjonujących jest odmienny, niż ten w którym żyją osoby zdrowe. Nawiązanie terapii kontaktowej z udziałem psa pomaga takim osobom nawiązać łączność z otaczającym światem. Kontakt $\mathrm{z}$ psem stanowi bazę do rozwoju relacji intelektualnej i duchowej. Grupę szczególną stanowią dzieci przewlekle chore poddawane często bolesnym i dość inwazyjnym metodom leczenia. Terapia z udziałem psa wpływa pozytywnie na psychikę dziecka, motywując go do udziału we właściwej aczkolwiek często nieprzyjemnej terapii. Dzieci 
mają szansę nabrać dystansu do swojego leczenia, cieszyć się chwilą, odzyskują radość życia. Terapia dzieci z niepełnosprawnościami odbywa się między innymi na zasadzie pomocy $w$ wykonywaniu codziennych czynności samoobsługowych (np. prowadzi dziecko będące na wózku, podaje przedmioty, otwiera drzwi). Często zdarza się, że zwierzę zmusza swojego pacjenta do aktywności fizycznej, np. przynosi dany przedmiot i zamiast podąć kładzie go pod nogi - dziecko musi wykonać ruch, aby go podnieść.

Pies terapeuta sprawdza się również w przypadku dzieci zdrowych, które doświadczyły sytuacji stresowych w życiu. Głaskanie i przytulanie się do psa jest dla dziecka źródłem bezpieczeństwa co pozwala na stopniowe otwieranie się go na świat zewnętrzny. Dzieci ze spektrum autyzmu początkowo nie zwracają uwagi na psa, który jest ich terapeutą. Z upływem czasu dziecko zaczyna ufać psu, przytula go, głaska, potrafi wydawać mu komendy. Jest to pierwszy krok do kontaktu ze światem zewnętrznym, często utrudnionego kontaktu (Pawlik -Popielarska, 2009). Pies terapeuta jest doskonałym słuchaczem, dlatego grupą odbiorców są również dzieci przejawiające trudności u uczeniu się czytania. Dziecko w atmosferze całkowitej akceptacji jest w stanie zapomnieć o swoim strachu i o ograniczeniach. Metoda czytania psu jest skutecznym sposobem na poprawę czytania u dzieci (Kulisiewicz, 2009).

Dogoterapia może być prowadzona również u dzieci, które przejawiają niedostosowanie społeczne oraz u skazanych przebywających w zakładach karnych. Obecnie w Polsce prowadzone są eksperymentalne programy profilaktyczne $\mathrm{z}$ udziałem psów.

Wzajemna interakcja człowieka ze zwierzęciem może mieć wiele korzyści zarówno dla osób dorosłych jak i dzieci. Jedną z nich jest rozwijanie empatii, czyli wczuwanie się w uczucia i sposób rozumowania innych. Na podstawie badań stwierdza się, że dzieci, które są wychowywane w domach, gdzie przebywa jakieś zwierzę mają większy poziom empatii i postrzegają zwierzęta na równi ze sobą. Empatia względem zwierząt jest łatwiejsza do osiągnięcia niż empatia względem ludzi, a wraz z dorastaniem dzieci ich umiejętność prawidłowego odgadywania uczuć zwierząt przenosi się także na ludzi co skutkuje poprawą relacji. Kolejną korzyścią jest skupienie się na świecie zewnętrznym - zwierzęta pomagają skupić się na środowisku zwłaszcza osobom cierpiącym na chorobę psychiczną lub mającą niską samoocenę. Dzieci uczą się wychowywać inną istotę, czują się akceptowane, a przede wszystkim potrafią się odprężyć (Filozof, 2004).

Pies terapeuta „przynosi radość i wywołuje uśmiech, pozwala rozwijać kontakty społeczne, poprawia komunikację, pozwala myśleć o czymś innym niż własna osoba, wiek, choroba, stymuluje ruch i aktywność, samodzielność i odpowiedzialność, daje możliwość okazania uczuć, wytwarza swoistą więź: człowiek - zwierzę, podwyższa pewność siebie, nadaje życiu sens, pomaga zdobyć nowych przyjaciół, ułatwia przejść przez samotność, chorobę i depresję, rozwija funkcje poznawcze, koncentrację uwagi, orientację przestrzenną, uczy samoakceptacji" (http://www.arka.chelm.pl/arka2/ str-zabawa_z_psem-85.html).

\section{Wyniki}

W przeprowadzonych badaniach wyodrębniono wiele korzyści z zastosowania metody dogoterapii. Można stwierdzić, że w każdym badanym przypadku pojawił się inny pozytywny skutek, dlatego trudno jest jednoznacznie określić główne i bazowe korzyści. Badani najczęściej wymieniali poprawę funkcjonowania dzieci w zakresie kontaktów interpersonalnych, rozwiniętą śmiałość i odwagę.

$\mathrm{Na}$ podstawie analizy badanych przypadków można wywnioskować, że dogoterapia pozytywnie oddziałuje na psychikę dziecka. W pierwszym przypadku u siedmioletniej Kamili występowały duże problemy z czytaniem spowodowane dysleksją rozwojową. Dziewczynka była przy tym nieśmiała i łatwo wpadała w złość, gdy nie udało jej się poprawnie przeczytać tekstów. Po zajęciach z suczką o imieniu Luna (Kamila uczęszczała na zajęcia przez pół roku, odbywały się one regularnie dwa razy w tygodniu w bibliotece miejskiej oraz w świetlicy środowiskowej. Terapia, w której udział brała zarówno Kamila jak i jej mama miały charakter luźnych zajęć, zwykle trwały około 45 minut) zauważono, że dziewczynka podejmuje próby samodzielnego czytania, mniej się denerwuje i odważniej wypowiada zdania. Pani Krystyna, mama Kamili powiedziała, że „na zajęciach dodatkowych coraz chętniej czytała jako pierwsza. Widać było ogromne postępy, nawet Pani pedagog była w szoku, że Kamila zrobiła duży krok do przodu w niedługim czasie. W domu też chętniej odrabiała prace domowe, cieszyła się z pozytywnych ocen i coraz mniej denerwowała się, że coś jej nie wychodzi. My z mężem tez próbowaliśmy ćwiczyć z nią jak najwięcej, żeby nie straciła zapału".

Kolejną badaną osobą była Karolina, dziesięciolatka, doświadczająca przemocy zarówno fizycznej, psychicznej jak i seksualnej ze strony ojczyma. Dziewczynka miała ogromne trudności w komunikacji zarówno z mamą jak i terapeutami. Nie opowiadała o swoich stanach emocjonalnych, nie odpowiadała na zadawane pytania.

Zdaniem mamy dziewczynki, Pani Beaty „Karolinka nawet podczas terapii grupowej nie chciała rozmawiać z rówieśnikami. Wiem, że to co się stało jest ogromną tragedią, ale ona w ogóle nie dawała sobie pomóc. Pisała kiedyś pamiętnik, niestety nawet to zaprzestała robić tak jakby całkowicie odcięła się od świata, od nas wszystkich".

Po wprowadzeniu do zajęć psa Karmela zaczęto zauważać minimalne postępy w rozwijaniu komunikacji u dziecka. Widoczny był wpływ zwierzę- 
cia na poziom zdenerwowania Karoliny, wyraźnie stawała się spokojniejsza i chętna do współpracy. Zajęcia prowadzone w grupie pięciorga dzieci przy udziale terapeuty oraz pedagoga miały różnorodny charakter od muzykoterapii przy udziale psa, poprzez zajęcia sportowe $w$ tym rzucanie psu piłki i zabawy w chowanego, aż do wspólnego czytania bajek i plastycznej twórczości. Podczas zajęć plastycznych, gdzie dzieci miały za zadanie odrysować posture psa na specjalnych kartkach Karolina dołączyła do zabawy. Na zajęciach z muzykoterapii, gdzie pies leżał na środku sali, a dzieci wokół niego Karolina wyraźnie się odprężała, zaczęła również współpracować z innymi. Chętnie czytała psu bajki i bawiła się z innymi dziećmi. Podczas czwartej sesji otworzyła się i zaczęła mówić o swoich problemach. Na końcowych zajęciach dziewczynka rozmawiała już z terapeutami i powoli pokonywała lęk przed rozmową $\mathrm{z}$ mamą, nie zamykała się już tak często w sobie i łatwiej opowiadała o swoich emocjach.

Następnym badanym przypadkiem był Karol, sześcioletni chłopiec ze spektrum autyzmu obdarzony talentem artystycznym. Przejawiał trudności w uczeniu się oraz w komunikacji z innymi. Chłopiec zamiast rozmawiać malował, swoje stany emocjonalne pokazywał na obrazach. Jak powiedziała pani Kasia, mama Karola „pamiętam, że mieliśmy spory problem z odczytaniem tego co Karolek potrzebuje, czasem płakał i nie można było go uspokoić, nie reagował na nasze prośby. To było dla nas straszne. Chcieliśmy mu pomóc, ale nie wiedzieliśmy jak, nie wiedzieliśmy nawet co się dzieje".

Kluczem do pracy dogoterapeutycznej z Karolem było malarstwo. Pies - Stefan zawsze miał na sobie pojemnik z farbą. Karol mógł z nim wspólnie malować, odbijać łapy. Trzy pierwsze spotkania miały za zadanie dotrzeć do chłopca, spróbować się z nim porozumieć, stworzyć mu przyjazne środowisko. Po trzech spotkaniach terapeutka chłopca zauważyła, że zaczął on wypowiadać pojedyncze słowa w kierunku psa, jednak robił to tylko do niego i nikomu innemu nie pozwalał się słyszeć. Rodzice obserwowali chłopca w domu jednak nie widzieli poprawy w jego zachowaniu. Po 9 spotkaniu podszedł do psa $\mathrm{z}$ namalowanym domem $\mathrm{z}$ ogrodem i zaczął mu opowiadać co robiła mama na śniadanie i gdzie je zjadł. To samo zrobił podbiegając do terapeutki. Stopniowo zaczęto wprowadzać elementy edukacyjne do zabawy ze Stefanem takie jak przyznawanie nagród chłopcu za prawidłowo wypowiedzianą komendę w kierunku psa. Chłopiec zaczął wypowiadać krótkie i proste zdania, a w badaniach okresowych stwierdzono poprawę umiejętności interpersonalnych w zakresie komunikowania się. Obecnie z Karolem dogoterapeuci pracują nad wzbogaceniem słownictwa dziecka oraz zwiększeniem poziomu pewności siebie.

Poprawę w zakresie umiejętności interpersonalnych można zauważyć również u Mateusza. Dziesięciolatek, który przebywa w Domu Dziecka przeszedł traumę po śmierci ukochanego taty. Manifestował to odcięciem się od społeczeństwa, zamknięciem w sobie, głęboką depresją oraz zaniechaniem nauki. Jego jedyną pasją była piłka nożna. Zdaniem pani Kingi, przewodniczki psa terapeuty „Tata był jedyną osobą, która w ogóle cokolwiek robiła dla tego chłopca. Matka porzuciła go we wczesnym wieku, babcia $\mathrm{z}$ powodu choroby rzadko go odwiedzała, miał tylko jego".

Po śmierci ojca chłopiec przeszedł traume i kontakt $\mathrm{z}$ nim był znacznie utrudniony. 0 swoich problemach opowiadał tylko Nikodemowi - koledze z Domu Dziecka. Mateusz nigdy się nie skarżył na swój los, płakał w samotności, nie pokazywał uczuć nikomu tylko. Na pytanie, dlaczego nie chce się uczyć, przecież jest bardzo ambitny odpowiadał „tylko tata mi dobrze tłumaczył". Dogoterapię prowadziła Pani Kinga z Olafem - 3 letnim psem rasy Samoyed. Podczas pierwszego spotkania chłopiec zachowywał się trochę nieufnie, chętnie bawił się $\mathrm{z}$ psem jednak odmawiał wykonywania czynności edukacyjnych. Podczas kolejnego spotkania chłopiec coraz bardziej się otwierał, najpierw wykonywał zadania, czytał psu książkę, a następnie po dobrze wykonanych poleceniach mógł zagrać $\mathrm{z}$ psem w piłkę. Schemat powtarzał się przez kolejne dwa tygodnie aż w końcu Mateusz chętniej zaczął współpracować z nauczycielami. Następnym krokiem było wprowadzenie Mateusza do grupy rówieśników w której również był pies Olaf. Chłopiec zaczął rozmawiać z innymi dziećmi, współpracował z terapeutami. Półroczne zajęcia pozwoliły na poprawę motywacji do nauki u chłopca. Mateusz stał się też odważniejszy.

Umiejętności społeczne znacznie poprawiły się również w przypadku Miłosza - dziesięcioletniego syna dogoterapeutki. Chłopiec urodził się z zespołem Downa, Pani Kasia, która jest jego mamą powiedziała, że: „Miłosz jest sklasyfikowany jako dziecko $\mathrm{z}$ niepełnosprawnością intelektualną $\mathrm{w}$ stopniu lekkim, więc całkiem dobrze radzi sobie w życiu. Przejawia natomiast duże problemy w komunikacji społecznej co czasami komplikuje z nim współpracę. Zdaniem terapeutów utrudniony kontakt ze światem najprawdopodobniej miał swoje podłoże w nieporadności, kiedy moje dziecko nie umiało sobie z czymś poradzić to automatycznie zamykało się w sobie". Na pierwsze indywidualne zajęcia z suczką rasy Border Collie Haną chłopiec poszedł pełen entuzjazmu jednak po jakimś czasie wycofał się. Nastąpiło to w momencie, gdy Hana spojrzała na niego i zmieniała pozycję z leżącej na siedzącą. Miłosz nieświadomie wykonał gest, który dla psa oznaczał komendę „siad”. Do końca zajęć przesiedział z dala od suczki na kolanach terapeutki. Zachowanie to poddało $\mathrm{w}$ wątpliwość dalsze leczenie tą metodą, ale podczas kolejnych zajęć, gdy wprowadzono już elementy zabawy polegające na odrysowaniu kształtu psa, ulepieniu jego postury z plasteliny czy nakarmieniu go chłopiec powoli przekonywał się do Hany. $\mathrm{Na}$ czwartych zajęciach nastapiło kolejne wycofanie, postanowiono zareagować od razu i gdy chłopiec siedział na kolanach terapeutki przewodnik 
psa pokazywał mu komendy do wykonania jedynie gestem. Hana posłusznie wykonywała wszystkie zadania przez co chłopiec myślał, że w ten sposób chce go zachęcić do zabawy. Stopniowo zbliżano się do psa, aby chłopiec mógł go spokojnie głaskać, gdy suczka na niego nie patrzy. Piąte spotkanie było przełomowe, chłopiec poderwał się z kolan terapeutki i sam zaczął dyktować psu zadania do wykonania, przyznawał mu za to również nagrody. Każde kolejne spotkanie przebiegało w podobny sposób. Chłopiec bardzo przyzwyczaił się do Hany, chętnie do niej mówił, pełen radości opowiadał wszystko swojej mamie, chętniej rozmawiał z terapeutą. Zajęcia z suczką Haną pozwoliły Miłoszowi odważniej wykonywać niektóre zadania, a w jego życiu coraz częściej pojawiał się uśmiech na twarzy, ekscytacja i chęć do rozmowy. Chłopiec pod wpływem dogoterapii znacznie rzadziej miewa napady złości i tylko niekiedy zdarza mu się nie rozmawiać z rodzicami Mama Miłosza tak zafascynowała się dogoterapią, że sami mają w domu suczkę Sarę, która pomaga chłopcu w codziennym funkcjonowaniu.

Nieco inną korzyść, a mianowicie rozwinięcie u chłopca poczucia odpowiedzialności wykazało badanie Bartka. Jedenastolatek mieszkający w placówce opiekuńczo-wychowawczej, przejawiał trudności w nauce oraz zachowania agresywne, autodestrukcyjne i ryzykowne. Pies Kapsel, który dość często odwiedza placówkę z przewodniczką Anną początkowo nie został przywitany najcieplej przez Bartek. Był wycofany, denerwowała go obecność psa. Pierwsza sesja trwała tylko pół godziny, ponieważ nie chciano, aby chłopiec całkowicie się zniechęcił. Podczas kolejnych zajęć wprowadzono elementy twórczości, ponieważ dobrym punktem odniesienia było wykorzystanie talentu chłopca do rozwiązywania zadań matematycznych. Pani Anna, która przewodziła psu nakazała by po każdym dobrze rozwiązanym rebusie matematycznym przynosił chłopcu swoje smakołyki i tym sposobem pozwalał się karmić. Powoli można było wprowadzać elementy nauki o zachowaniu się zwierząt; również o agresji i o tym jak oddziałuje ona zarówno na ludzi jak i na inne zwierzęta. Chłopiec uczył się jak opiekować się psem, czego mu potrzeba i jak należy go wychowywać. Miało to na celu wzbudzenie w nim poczucia odpowiedzialności za czyjeś życie oraz konsekwencji swoich zachowań. Zdaniem Pani Anny, przewodniczki psa terapeuty „Bartek jest dobrym dzieckiem, wiele w życiu przeżył. To miało wpływ na jego zachowanie, ale dzięki Kapselkowi wszystko powoli się normuje; powiedziałabym nawet, że stali się dobrymi przyjaciółmi. Mój pies bardzo lubi swoich podopiecznych, ale Bartka chyba polubił szczególnie (śmiech)". Chłopiec znacząco poprawił wyniki w nauce, a przede wszystkim nauczył się odpowiedzialności za drugą istotę.

Półroczna terapia dała podstawę do dalszej pracy z Bartkiem, który zaczął panować nad swoim zachowaniem. Teraz sam wychowuje szynszyla i uczy inne dzieci jak dbać o zwierzęta.
Kolejnym przykładem korzyści innych niż poprawienie komunikacji interpersonalnej jest sytuacja Sylwii. U dziewięcioletniej Sylwii zdiagnozowano przepuklinę kręgu lędźwiowego, która zaczęła znacznie uciskać rdzeń kręgosłupa co uniemożliwiało chodzenie. Niestety po operacji dziewczynka dalej nie mogła chodzić i czekała ją długa rehabilitacja. Pani Emilia, mama dziewczynki powiedziała, że: „w tym czasie moja córka całkowicie się załamała. To tak jakby zabrać piłkarzowi piłkę i powiedzieć, że może nigdy już nią nie zagra. Jej koleżanki biegały po podwórku, a ona płakała po katach, gdy musiała wsiąść każdego kolejnego dnia na swój wózek, zupełnie nie mogła tego zrozumieć". Dziewczynka straciła poczucie własnej wartości, opadła z sił, męczyła ją rehabilitacja, nie emanowała już optymizmem. Sylwia w Zakopanem, gdzie przechodziła rehabilitację spotkała Kamę - czarnego Labradora, który od razu przypadł jej do gustu. Dziewczynka spotykała się z psem kilka razy w miesiącu. Ich spotkania polegały przede wszystkim na wspólnej zabawie, ale i na rehabilitacji również. Wykorzystywano Kamę do zachęcenia dziewczynki do ćwiczeń zwłaszcza w basenie. Polegało to na tym, że pies podpływał do Sylwii a ona rzucała mu piłkę. Za każdym razem dziewczynka wraz z terapeutą starała się przepłynąć kilka metrów. Sylwia i Kama zaprzyjaźniły się na tyle, że dziewczynka całkowicie pogodziła się z sytuacją i zaczęła dzielnie stawiać czoła swojemu problemowi. Obecnie Sylwia dalej jeździ na wózku inwalidzkim jednak odzyskała częściowo czucie w lewej stopie i robi postępy w rehabilitacji.

Po procesie terapii dużą poprawę wykryto w sprawności ruchowej dziewczynki, odzyskała również wolę walki o swoje zdrowie i nie okazuje już objawów depresji. Pomoc suczki okazała się na tyle ważna w życiu dziecka, że do tej pory chodzą razem do szpitala dziecięcego by wspólnie wspierać innych w walce $\mathrm{z}$ chorobami przewlekłymi.

Rozmowy z przewodnikami psów terapeutów pozwalają wysnuć wniosek, że najczęściej pojawiającymi się korzyściami dogoterapii jest poprawa W zakresie funkcjonowania społecznego, rozwój ruchowy, wzrost odwagi, odczuwanie radości z życia codziennego oraz wzrost motywacji do działania. Pani Ania, przewodniczka psa Kapsla jest zdania, że „mali pacjenci lepiej reagują na obecność psa i innych zwierząt niż obecność obcych ludzi, dlatego warto poprzedzić np. rozmowę z psychologiem zabawą z psem".

Przeprowadzone badania dowodzą, że korzyści $\mathrm{z}$ metody dogoterapii jest wiele. Nawet jeśli nieznacznie poprawia ona funkcjonowanie dziecka w jednym zakresie, zawsze w pozytywny sposób wpływa na inny obszar. Wielu autorów wymienia podobne korzyści pojawiające się $\mathrm{w}$ terapii $\mathrm{z}$ udziałem psa co dowodzi, że ta stosunkowo nowa metoda ma szansę odnieść wielkie sukcesy w rozwoju i rehabilitacji dzieci i młodzieży. 


\section{Wnioski}

Dogoterapia jako jedna $\mathrm{z}$ metod wspomagających proces rozwoju i rehabilitacji zarówno dzieci jak i osób dorosłych jest pojęciem znanym, jednakże stosunkowo niedawno znacznie przyczyniła się do poprawy procesu leczenia. Od lat zwierzęta brały czynny udział w życiu człowieka, a w ostatnim czasie ich oddziaływanie chociażby na samopoczucie stało się podstawą do stworzenia nowatorskiej metody rehabilitacji. Według wielu autorów pies jest swoistym motywatorem do działania. Dzięki przyjemnemu usposobieniu oraz cierpliwości i posłuszności staje się idealnym terapeutą dla osób mających kłopoty w codziennym funkcjonowaniu. Pies przełamuje bariery jako istota żywa, nie oceniająca, nie ponaglająca oraz nie wyśmiewająca się z ludzkich niedoskonałości, obdarzajacca zaufaniem i bliskością dzięki czemu podopieczni mogą czuć się bezpiecznie zarówno na zajęciach indywidualnych jak i grupowych.

Badania, które zostały przeprowadzone ukazują opinie rodziców i dogoterapeutów na temat tego w jaki sposób dogoterapia wspomaga rozwój oraz rehabilitację dzieci. Analiza wyników badań pozwala na stwierdzenie, że dogoterapia zwana inaczej kynoterapią jest bardzo dobrą alternatywą dla tradycyjnych metod leczenia, jednak nie nadaje się do wykorzystania we wszystkich przypadkach. Pomimo leczniczych działań dogotepii istnieją czasem poważne przeciwwskazania do jej wykorzystania. Do zajęć dogoterapeutycznych nie mogą być skierowani pacjenci posiadający otwarte rany na ciele, alergię na sierść psa, przejawiający paniczny lęk wobec zwierząt, pacjenci agresywni, z ADHD, pacjenci ze schorzeniami psychicznymi. Z tych powodów wybór dogoterapii jako metody wspomagającej rehabilitację powinien być wcześniej potwierdzony odpowiednimi informacjami na temat stanu zdrowia psychicznego pacjenta, poziomu jego agresji oraz występowania innych cech niepożądanych.

Według przewodniczki psa Olafa pani Kingi „nie każdy pies nadaje się do dogoterapii tak samo jak nie każdy pacjent powinien się na taką terapię wybrać. Musimy chronić przede wszystkim dobro dzieci jak i naszych czworonogów, nie możemy dopuścić do sytuacji, żeby osoby przejawiające agresję wobec zwierząt uczestniczyły w naszych zajęciach". Niektóre rasy psów nie powinny być wykorzystywane w dogoterapii np.: duże i groźne rasy stróżujące (typu owczarek środkowo-azjatycki, owczarek kaukaski oraz jużak); psy z ras pasterskich i stróżujących, których cechą przewodnią jest nieufność do obcych; psy z rasy pinczerów, które cechuje hałaśliwość i zbyt duży temperament (np. doberman, pinczer, ratlerek czy sznaucer); bokser ze względu na zbyt euforyczne okazywanie radości; psy z mo- losowatych (czyli rottweiler, dogi oraz mastiffy) ze względu na dużą niechęć do podporządkowania się człowiekowi; teriery ze względu na niezależny charakter i upór. Przerwanie procesu dogoterapii następuje również w wyniku nasilenia się epilepsji, ciężkiej choroby psa, cieczki u suczki lub ciąży.

Badania wykazały, że ta forma terapii jest coraz częściej stosowaną metodą pomocniczą w leczeniu osób zmagających się z niepełnosprawnościami. Pani Emilia mama dziewięcioletniej Sylwii cierpiącej na niedowład kończyn dolnych przekonuje, że „na dogoterapię namówiła mnie koleżanka z pracy. Kiedyś coś o tym czytała, później wzięła udział w takich zajęciach ze swoim mężem, który stracił rękę podczas pracy za granicą i całkowicie się załamał. Przekonała mnie, że to właśnie pies pomógł mu odzyskać radość życia, dlatego odważyłam się i spróbowałam z moją Sylwią". Pies został także terapeutą dzieci, które zmagają się z trudnościami w czytaniu, depresją po stracie bliskich, załamaniem spowodowanym przemocą w rodzinie, spektrum autyzmem, zespołem Downa oraz autoagresją. Każdemu z tych przypadków postawiono cele jakie należało osiągnąć poprzez proces dogoterapii. Zebrany materiał dowiódł, że zarówno cele edukacyjno-poznawcze oraz cele w zakresie zdrowia psychicznego jak i cele motywacyjne zostały całkowicie lub częściowo osiągnięte w dość krótkim odstępie czasowym. Uściślając można stwierdzić, że w przypadku dzieci z zaburzeniami rozwojowymi dogoterapia wpłynęła pozytywnie na aspekty edukacyjno-poznawcze, natomiast w przypadku Sylwii, która zmaga się z niedowładem kończyn wyraźnie zostały spełnione cele motywacyjne, a następnie cele w zakresie zdrowia psychicznego.

Analiza wyników badań pozwoliła na wysnucie wniosku, że korzyści jakie niesie za sobą proces dogoterapii są inne dla każdego z badanych przypadków co wynika przede wszystkim z przyjętych wcześniej celów oraz z różnorodności problemów $\mathrm{z}$ jakimi zmagają się badani. Można jednak zauważyć, że powtarzającymi się korzyściami praktycznie w każdym przebadanym przypadku są: poprawa kontaktów interpersonalnych, wzmocniona wiara we własne możliwości, podniesienie poczucia własnej wartości oraz nabywanie nowych kompetencji społecznych. Obecność czworonoga na zajęciach pozwala dziecku odprężyć się, wyciszyć, obniża poziom lęku oraz kształtuje trwałą więź. Badania ukazały, że głównymi korzyściami z zastosowania dogoterapii jest zdecydowana poprawa w różnych sferach: sferze społecznej (kontaktów interpersonalnych), sferze samooceny (rozwinięta śmiałość i odwaga), sferze senso-motorycznej (mówieniu, czytaniu, poruszaniu się, kontrolowaniu emocji),sferze motywacji do działania czy rozwinięcia poczucia odpowiedzialności. 


\section{Literatura:}

1. Bartkiewicz, W., Zawadka, M. (2008). Pies terapeuta i przyjaciel rodziny. Rola psa w procesie rehabilitacji niepełnosprawnego dziecka. Warszawa: Przyjaciel.

2. Czerwińska, M. (2016). Ważne wydarzenia. Pobrane z: http://www.czeneka.org/index.php?dzial=czeneka

3. Drwięga, G., Pietruczuk, Z. (2014). Dogoterapia: prawdy i mity. Białystok: Prymat.

4. Drwięga, G., Pietruczuk, Z. (2015). Dogoterapia jako forma wspomagania rozwoju dziecka niepełnosprawnego. Niepełnosprawność - zagadnienia, problemy, rozwiqzania, 3(16), s. 58-59.

5. Filozof, J. (2004). Dogoterapia? Co to jest? Jarosław: Polskie Stowarzyszenie na rzecz osób z upośledzeniem umysłowym.

6. Franczyk, A., Krajewska, K., Skorupa, J. (2012). Baw się poprzez animaloterapię. Przykłady gotowych sytuacji edukacyjnych z udziałem zwierząt. Kraków: Impuls.

7. http://poradniakielce.pl/oferta/terapia/dogoterapia/

8. http://www.arka.chelm.pl/arka2/str-zabawa_z_psem-85.html

9. https://dogoterapia.wordpress.com/artykuly/dogoterapia/

10. Kulisiewicz, B. (2007). Witaj, piesku! Dogoterapia we wspomaganiu rozwoju dzieci o specjalnych potrzebach edukacyjnych. Kraków: Impuls.

11. Kulisiewicz, B. (2009). Dogoterapia we wspomaganiu nauki i usprawnianiu techniki czytania. Kraków: Impuls.

12. Machoś-Nikodem, M. (2006). Rola kynoterapii (dogoterapii) w usprawnianiu komunikacji małego dziecka z deficytami rozwojowymi. W: M. Włodarczyk-Dudka (red.), Terapia psychopedagogiczna z udziałem psa. Wybrane zagadnienia (s. 78-88). Ostróda: Drwęca.

13. Machoś-Nikodem, M. (2017). Dogoterapia w pracy logopedycznej. Pobrane z: http://yadda.icm.edu.pl/ yadda/element/bwmeta1.element.desklight-0cca0907-ff11-406d-a4d1-99dbb4a3e64d/c/17_MachosNikodem_159-172_.pdf

14. Marszałek, M. (2013). Pies na etacie czyli dogoterapia. Pobrane z: http://www.deon.pl/inteligentne-zycie/psychologia-na-co-dzien/art,125,pies-na-etacie-czyli-dogoterapia.html

15. Nawrocka, J. (2009). Dogoterapia jako metoda wspomagania rehabilitacji dziecka z zaburzeniami rozwoju. W: W. Samborski, E. Gajewska (red.), Dziecko niepełnosprawne. Narzędzia diagnostyczne i terapeutyczne (s. 120-135). Poznań: Wydawnictwo p to q.

16. Otto J. (2010). Dogoterapia w terapii autyzmu. W: E. Pisula, D. Danielewicz (red.), Wybrane formy terapii i rehabilitacji osób z autyzmem (s. 180-195). Kraków: Impuls.

17. Pawlik- Popielarska B. (2005). Terapia z udziałem psa. Gdańsk: Via Medica.

18. Pieczyńska, N., Nawrocka-Rohnka, J., Urban, M. (2012). Dogoterapia i dogoaktywności - podobieństwa i różnice, Poznań: Dabart. 